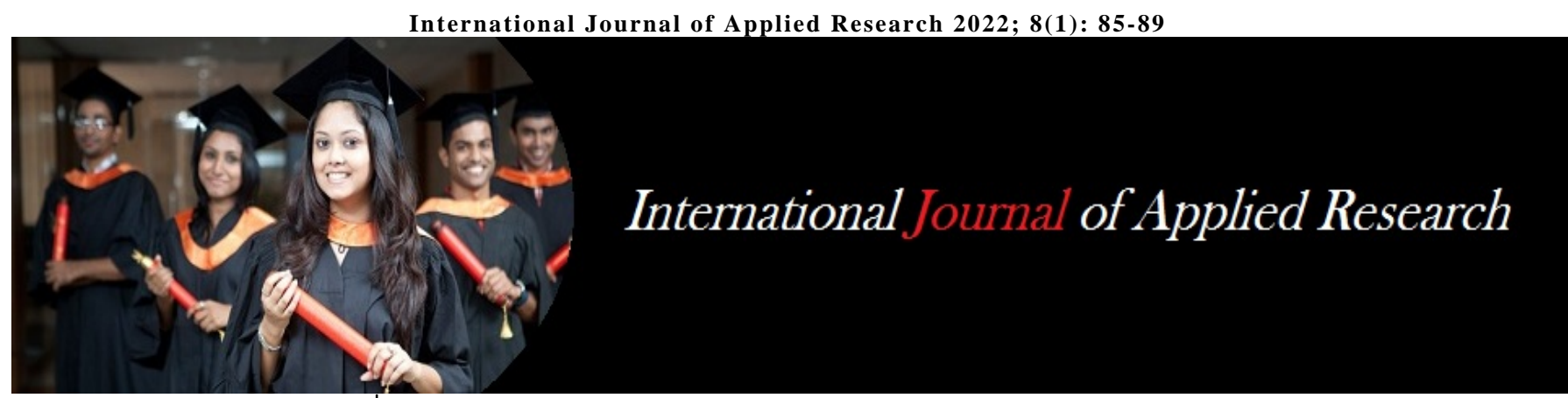

ISSN Print: 2394-7500

ISSN Online: 2394-5869

Impact Factor: 8.4

IJAR 2022; 8(1): 85-89

www.allresearchjournal.com

Received: 19-11-2021

Accepted: 21-12-2021

J Judith Gracia

Research Scholar,

Department of English and

Research Centre,

Sarah Tucker College

(Autonomous),

Affiliated to Manonmaniam

Sundaranar University,

Abishekapatti, Tirunelveli,

Tamil Nadu, India
Corresponding Author:

J Judith Gracia

Research Scholar,

Department of English and

Research Centre,

Sarah Tucker College

(Autonomous),

Affiliated to Manonmaniam

Sundaranar University,

Abishekapatti, Tirunelveli,

Tamil Nadu, India

\section{Lyrical and Stylistics Study of Psalm 23}

\section{J Judith Gracia}

DOI: https://doi.org/10.22271/allresearch.2022.v8.i1b.9311

\section{Abstract}

The research paper focuses on the lyrical, linguistic and literary style of Psalm 23. The book of Psalms in the Bible is a recognised piece of literature. David has written many Psalms, and seventy-three are ascribed to him. Among these Psalms, Psalm 23 is worldly and widely acknowledged as David's and the most read and recited one. Though many have not read the Bible, they are familiar with the first verse of the Psalm "The LORD is my shepherd; I shall not want" (23:1). There is much more to discuss in Psalm 23 than just discussing the shepherd. The style is distinctly Davidian, and the themes range from earthly to heavenly and filled with detailed expressions from his experiences in metaphoric imagery. The analysis shows that the use of archaic words are still in use, and it is highly praised by how it is arranged in a sentence. The choice of words boosts the energy of a reader in times of need and gives the poetry a sense of belonging by the subjective themes, structure and form. Though Psalms were written about centuries ago, they still have life and comfort people today.

Keywords: psalms, lyric, grammar, metaphor

\section{Introduction}

Acknowledging the words of Wordsworth, "Poetry is the spontaneous overflow of powerful feelings", this lyric Psalm 23 is based on the poet David's personal life that shares his lifestyle to the other world (Chickera 180). As poetry is the powerful feelings of a poet, lyric poetry is nothing but subjective, and it is like a pearl taken from the rare ends of the sea, and it is magical. David's Psalms echoes the people's minds unconsciously and makes the reader experience the inexperienced, which is the magic of lyric poetry. Even Gregory Bateson says that "All experience is subjective” (Gregory Bateson Quotes). The best experiences are produced in the form of poems or songs. David's experience is shared by using figurative language.

\section{Materials used}

The researcher has used the online version of the King James Bible published by King James during the year 1611 in the Cambridge edition and as well as referred to a few scientific journal articles, textbooks and videos.

\section{Language of Psalms and its structure}

Psalms are originally written in ancient languages such as Hebrew and Aramaic. They have their own characteristics, structured patterns and sentence arrangement in poetry. The quality of the language is profane and divine since the Holy Spirit initiates it. David's poetry is figurative and symbolic. Prophet Samuel in the Bible mentions that David is a sweet singer of Israel, but according to today's context, the word sweet ironically implies the sweetened or a thin voice of a singer rather than taste. Each line is noted by a colon (Futato and Jr., 2007). Each line has separate thoughts, and the verse is arranged in couplets, and in some verses, it has two or three lines.

The structure in Psalm 23 consists of thirteen lines divided by a colon according to the definition of Futato.

1. The LORD is my shepherd;

2. I shall not want.

3. He maketh me to lie down in green pastures: 
4. He leadeth me beside the still waters.

5. He restoreth my soul:

6. He leadeth me in the paths of righteousness for his name's sake.

7. Yea, though I walk through the valley of the shadow of death, I will fear no evil:

8. for thou art with me;

9. Thy rod and thy staff they comfort me.

10. Thou preparest a table before me in the presence of mine enemies:

11. Thou anointest my head with oil; my cup runneth over.

12. Surely goodness and mercy shall follow me all the days of my life

13. And I will dwell in the house of the LORD for ever.

\section{Figurative language and themes}

Unlike English poetry, Psalms do not rhyme, but they rhyme in thoughts.

Table 1. Rhyme Scheme

\begin{tabular}{|c|c|c|}
\hline Last word of the verse & Rhyme & Rhyme Scheme \\
\hline want & nt & a \\
\hline waters & ers & b \\
\hline sake & ke & c \\
\hline me & me & d \\
\hline over & er & e \\
\hline ever & er & e \\
\hline
\end{tabular}

From table one, it is clear that there is a rhyme scheme found in the last two verses. The rhyme scheme is an ordered pattern that helps to recollect, recite, remember and embellish with a musical touch. Britannica says, "rhyme scheme, the formal arrangement of rhymes in a stanza or a poem". The pattern is noted by lowercase as a-b-c-d-e-e, and the poet has arranged it freely. It is unique and does not resemble any of the poems in English literature. The reason is that Psalms are translated from the Hebrew language, but the translators of English have managed to bring to the form of English poetry. Comparatively, Emily Dickinson poems have this pattern of rhyme scheme.

The theme in David's Psalms is lament and thanksgiving to God. Psalm 23 can be called a "Psalm of faith". Because of profound themes, Psalm 23 is recited and looked to during times of trouble, recited and sung at the house of death and during the wedding service. This Psalm is moralistic, metaphoric and inspirational. The first three verses give a positive light on the theme of his personal experience, and then in verse four, he brings a darker theme of assumption and concludes with faith in the Lord. "Yea, though I walk through the valley of the shadow of death, I will fear no evil: for thou art with me; thy rod and thy staff they comfort me" (Psalm 23:4). In verse five, the poet changes the audience to the Lord, and he says with confidence that the Lord is serving him and prepares a banquet before his enemies and blesses him with the richest blessings. The Psalm ends with an assurance that the Lord will provide him with good things all through his life, and he makes a place in eternity, "Surely goodness and mercy shall follow me all the days of my life: and I will dwell in the house of the LORD for ever" (23:6).

Psalm 23 is packed with imageries and figurative language. The first line begins with a metaphor. Stanford Encyclopedia states that metaphor, "made to stand for another word". Similarly, the word shepherd refers to the shepherd's attribute instead of the Lord. The poet David portrays himself as a sheep. The first two verses are an extended metaphor of shepherd and sheep. "The LORD is my shepherd; I shall not want. / He maketh me to lie down in green pastures: he leadeth me beside the still waters" (Psalm 23:1, 2). The image of a shepherd is common in near eastern Israel. According to the Bible, it is a family job in all families. The youngest member in the family is to look after the sheep. This must be the situation in David's life because he is the last son of his parents. As a result, he has become a shepherd to his flocks and uses an image from his personal experience. Sheep are essentially meek animals that graze in groups and have almost no predator protection. The poet must have been experienced fear like the sheep and thus begins the poem as "The LORD is my shepherd" (Psalm 23:1). Sheep achieve maturity at about one year of age, and many breeds at about one and a half years. The poet wants the Lord to be his shepherd to take care of him until he matures.

The use of imageries give life and form in these phrases "lie down in green pastures, still waters, valley of the shadow of death, rod and staff, a table, head with oil, cup runneth over are pictorial, aural, kinesthetic and emotional. These imageries are from the experiences of the poet who brings the image from his mind to words in a poetic language. S. H Burton echoes as, "Imagery in poetry is an appeal to the senses through words. Through the senses, the emotions and the intellect of the reader can be swiftly stirred" (Burton, 1950).

\section{Style}

Style is the exceptional quality that gives a glossy shade to the poem from the choice of words, the number of words, and the sentences used to create a beautiful image. Style is the poet's thumb impression that is unique, distinct and cannot reciprocate. Similarly, in their article, Mrs and $\mathrm{Mr}$ Quackenbush quote Stephen as he declares, "style is usually individual, his literary fingerprint” (Quackenbush \& Quackenbush, 2019). Style refers to how it is said, and the poet conveys his thoughts in words to express the particular tone or character. Style is a unique way to analyse, study and study the poet's work. Leech and Short explain style as "it refers to the way in which language is used in a given context, by a given person, for a given purpose, and so on" (Short \& Leech, 2007).

\section{Words}

The colloquial words reflect the poet's culture and trigger the reader's interest in exploring the poet's native place, experience, and challenges. The essential aspects while still expressing the complexity of thinking through the use of words - the morphology, grammatical structure, vocabulary, and diction. Understanding the Psalms need a solid analysis of the meaning and arrangement of words. Many English poets became great poets by reading the poetry from the Bible, especially David's. Next, the analysis of the combination of words and structure of the poem helps to know the reason why the poet has framed it in a certain way and paves the way for ideas. The combination of words or vocabulary used is lexical, and structuring or arranging the words is syntactic. For example, it is the study of figurative language. The succeeding analysis is on the placement of words in a sentence, for instance, the parts of speech. 
Table 2. Parts of Speech used

\begin{tabular}{|c|c|c|c|c|c|c|c|}
\hline Noun & Pronoun & Verb & Adjective & Adverb & Conjunction & Preposition & Interjection \\
\hline $\begin{array}{c}\text { LORD shepherd waters soul } \\
\text { pastures paths } \\
\text { righteousness name sake valley } \\
\text { death fear } \\
\text { art thou rod staff } \\
\text { comfort table presence enemies } \\
\text { head } \\
\text { oil cup } \\
\text { goodness mercy life house LORD }\end{array}$ & $\begin{array}{l}\text { my I } \\
\text { He me He me } \\
\text { He my He me } \\
\text { His I } \\
\text { me thy they } \\
\text { me thou me } \\
\text { mine thou my } \\
\text { my me my }\end{array}$ & $\begin{array}{c}\text { is shall want } \\
\text { maketh lie down } \\
\text { leadeth restoreth } \\
\text { leadeth } \\
\text { walk preparest } \\
\text { anointest runneth } \\
\text { shall follow will } \\
\text { dwell }\end{array}$ & $\begin{array}{c}\text { green still } \\
\text { shadow evil }\end{array}$ & $\begin{array}{l}\text { not through } \\
\text { no } \\
\text { over surely } \\
\text { all days } \\
\text { forever }\end{array}$ & $\begin{array}{l}\text { though and } \\
\text { and and }\end{array}$ & $\begin{array}{c}\text { to in } \\
\text { beside in of } \\
\text { for of for } \\
\text { with before in } \\
\text { of with of in }\end{array}$ & уеа \\
\hline
\end{tabular}

Table two displays parts of words used by David in his Psalm. Solomon, son of David in Proverbs says, "Pleasant words are as an honeycomb, sweet to the soul, and health to the bones" (16:24). The pleasant words of verbs show a list of sixteen actions and expressions that the Lord performed to David when he asked for it. Especially the irregular and regular verbs maketh, leadeth, restoreth and preparest are the enjoyable and pleasing feel that the Lord provides the poet. He is the God of today, as David uses 'is' in verse one. The poet writes in the future perfect tense using shall and will with negative contraction in verse one. The use of this tense proves the definite faith, trust, and hope he has in God that He will not leave empty and takes care of everyone with the utmost care, and the poet enjoys all the richest blessings in God's house. The category of pronouns is five possessive adjectives and pronouns (my), seven personal pronouns (me), two first persons (I) and one possessive pronoun (mine).

David is meticulous in the choice of words and uses it with a personal touch as he uses the first person and nouns the naming part more than other parts of speech, proving that the poem is subjective. Though the words are short, they have a deeper meaning. Again, Solomon mentions that "The words of a man's mouth are deep waters; The wellspring of wisdom is a flowing brook" (Proverbs 18:4). Besides nouns and pronouns, the action and motion of words verbs encourage the readers to have a movement in their thoughts as it gives kinesthetic imagery. The syntactic function is well-balanced by other parts of speech. As literature is full of words, this table assists in analysing how the poet has used in his poem to give a colour, a sense of action, a recognition to the subject and connectors to connect his ideas.

Table 3. Periods of words

\begin{tabular}{|c|c|}
\hline Archaic & Modern \\
\hline maketh & make \\
\hline leadeth & lead \\
\hline restoreth & restore \\
\hline yea & yes \\
\hline thou & you \\
\hline thy & your \\
\hline preparest & prepare \\
\hline anointest & anoint \\
\hline runneth & run \\
\hline
\end{tabular}

Table three lists the archaic words in Psalm 23, which were frequently used during the olden days and changed after the romantic age. The use of archaic language preserves the poem's rhythm, intonation, as well as its ancient tone and originality. The sound patterns from these words give rise to creating an effect while reading. For example, maketh, leadeth, restoreth and runneth have identical end rhyme and preparest, anointest rhymes similar. These terms are familiar because they are repeated in middle-aged authors and writers such as Shakespeare, Donne, Spencer, and Milton, even though they are not commonly used in today's English. This archaism is a figure of speech considered outdated or old-fashioned and not obsolete. Because some words such as 'yea', 'thou' and 'thy' are still in use. Other than the archaic words, the kinds of sentences are simple sentences, and the thoughts are affirmative from the beginning to the end. This reflects the poet's mood and feelings towards the Lord, his shepherd.

\section{Punctuation}

Punctuations are the marks to stop or pause and to analyse the sentence. William Livingston Klein exclaims that "it deals with the finest shades of meaning possible in the arrangement of words in the written language" (Klien, 1897). The chief punctuations are indeed the period, colon, semicolon, interrogation, apostrophe, and it gives meaning to the sentences. The semicolon connects the complex sentences, and the colon serves as a transition between thoughts, and the period in a sentence shows the ending of a thought process and the beginning of the next one. Interestingly there is an absence of a comma in the poem. There is only one apostrophe or possessive case in Verse three, referring to the Lord's name's sake. Table four gives a list in detail.

Table 4. Punctuations Used

\begin{tabular}{|c|c|c|}
\hline Punctuations & Title of the punctuation & Verse number \\
\hline$;$ & semicolon & $1,4,5$ \\
\hline$;$ & period & $1-6$ \\
\hline$:$ & colon & $2-6$ \\
\hline$;$ & apostrophe & 3 \\
\hline
\end{tabular}

\section{Lyric poetry}

Lyric is well-defined by its characteristic features. The nature of lyric poetry is "simple, short, intense and attractive alterations" of an emotional speech where this idea has developed in the Romantic age (Greene 216; Burt 7-8). According to the King James Bible, this Psalm has six verses. Comparatively to any English poetry, this Psalm is short, and the first line of the poem serves as an introduction to the poem. Scott Brewster's rendition to lyric as "it is characterised by brevity, deploys a first-person speaker or persona, involves performance, and is an outlet for personal emotion" (1). David uses the first person singular possessive determiner to emphasise the first persona throughout the 
poem. Thus it is said that Psalm 23 is in the form of lyric poetry.

Table 5. First Persona

\begin{tabular}{|c|c|c|}
\hline Verse number & Lines of the poem & First Persona \\
\hline 1 & He maketh me to lie down in green pastures: he leadeth me beside the still waters. & My, I \\
\hline 2 & He restoreth my soul: he leadeth me in the paths of righteousness for his name's sake. & He, me \\
\hline 3 & $\begin{array}{c}\text { Yea, though I walk through the valley of the shadow of death, I will fear no evil: for thou art with me; } \\
\text { thy rod and thy staff they comfort me. }\end{array}$ & I, me \\
\hline 4 & $\begin{array}{c}\text { Thou preparest a table before me in the presence of mine enemies: thou anointest my head with oil; my } \\
\text { cup runneth over. }\end{array}$ & Me, mine, my \\
\hline 5 & $\begin{array}{c}\text { LoRD for ever. } \\
\text { Lurely goodness and mercy shall follow me all the days of my life: and I will dwell in the house of the }\end{array}$ & Me, my, I \\
\hline
\end{tabular}

From table five, it is clear that the use of 'my, me, mine and I' assures the "self-communing and introspective" role of the poet "rather than a form of utterance concerned to locate an audience" (Brewster, 2009). When the poem is read by someone else, it makes the reader personalised as the speaker is written in the first persona. Likewise, Howe comments that "A characteristic feature of the lyric I is precisely this vagueness that allows the reader to equate it with the poet, perhaps; to identify with it himself, or herself; or to see it as a universal I belonging to no-one and to everyone” (ibid.:32). An interesting part of Psalm 23 is that the poet uses 'I' only in verses 1,4 , and 6 , which shows the personal space between him and God.

\section{Word stress}

Word stress is a key in communication, and it helps to understand what the other person says when he stresses words of his choice. The recognised word stress is easily understood when it is said relatively the misplaced word stress changes the meaning of a sentence. The importance of word stress in this Psalm is felt when read or recited in temples, churches, and during special occasions.

Table 6. Composition of Psalm 23 (Unstressed - Stressed /)

\begin{tabular}{|c|c|c|c|c|c|c|c|c|c|}
\hline Verse & - & I & - & I & - & I & - & I & - \\
\hline 1 & The & LORD & is & my shep & -herd & I & shall & not & want \\
\hline Verse & - & I & - & l & - & I & - & I & - \\
\hline \multirow[t]{2}{*}{2} & $\mathrm{He}$ & maketh & me to & lie down & in & green pas & -tures & he leadeth & me \\
\hline & be & -side & still & wa & ters & & & & \\
\hline Verse & - & I & - & 1 & - & 1 & & - & I \\
\hline \multirow[t]{2}{*}{3} & $\mathrm{He}$ & resto & -reth & $\begin{array}{l}\text { my } \\
\text { soul }\end{array}$ & he & \multicolumn{2}{|c|}{ leadeth } & me in the & paths \\
\hline & of & right & $\begin{array}{c}- \\
\text { eousness } \\
\end{array}$ & for his & name’s & \multicolumn{2}{|c|}{ sake } & & \\
\hline Verse & - & 1 & - & 1 & - & \multicolumn{2}{|l|}{1} & - & 1 \\
\hline \multirow[t]{3}{*}{4} & $\begin{array}{c}\text { Yea } \\
\text { though }\end{array}$ & I walk & $\begin{array}{l}\text { through } \\
\text { the }\end{array}$ & valley & of the & \multicolumn{2}{|c|}{ shadow } & of & death \\
\hline & I & fear & no & evil & $\begin{array}{c}\text { for thou } \\
\text { art }\end{array}$ & \multicolumn{2}{|c|}{ with me } & thy & rod \\
\hline & and thy & staff & they & com & -fort & \multicolumn{2}{|c|}{ me } & & \\
\hline Verse & 1 & - & I & - & 1 & \multicolumn{2}{|l|}{ - } & 1 & - \\
\hline \multirow[t]{3}{*}{5} & Thou & pre & -parest & $\mathrm{a}$ & table & \multicolumn{2}{|c|}{ before } & me & in the \\
\hline & presence & of & mine ene & -mies & thou & \multicolumn{2}{|l|}{$\mathrm{a}$} & -nointest & my \\
\hline & head & with & oil & my & cup & \multicolumn{2}{|c|}{ run } & -neth & over \\
\hline Verse & - & 1 & - & 1 & - & \multicolumn{2}{|l|}{ I } & - & I \\
\hline \multirow[t]{3}{*}{6} & Surely & goodness & and & mercy & shall & \multicolumn{2}{|c|}{ follow me } & all the & days \\
\hline & of my & life & and & $\mathrm{I}$ & will & \multicolumn{2}{|c|}{ dwell } & in the & house \\
\hline & of the & LORD & for & ever & & & & & \\
\hline
\end{tabular}

In table six, the composition of the unstressed and stressed words highlights the importance of the choice of words and the rhythm in verse. There is a structured pattern as unstressed-stressed- unstressed-stressed-unstressed-stressedunstressed-stressed-unstressed-stressed-unstressed- stressedunstressed-stressed-unstressed. The absence of the meter gives a different form and is called irregular meters or asymmetrical meters. Similarly, Susan Stewart remarks that "Poetic meter is a pattern of marked linguistic features and their absence shapes a poetic line" (53). Each verse is composed of twenty syllables in seven pairs of unstressed and stressed syllables. There are 105 monosyllabic words in this poem out of 116 words, which is 91 per cent, and there are repetition words too. Since the words are short and catchy, they attract readers to read them with heart and mind ease. "Short words are best", said Winston Churchill, "and old words when short are the best of all” (The Economist).

\section{Conclusion}

To summarise, the study of Psalm 23 shows a wellstructured arrangement of word order and sentence structure in sequence. However, there is no repetition, rhyme scheme, or comma, most common in poems. Even the lines are irregular, something quite new in seventeenth-century 
English poetry. Nevertheless, thoughts are delivered straight with short, attractive and crisp words. Most notably, without a doubt, it is the most recognised and renowned of all Psalms. Comparatively from David's other seventy-two Psalms, this poem is inimitable and customisable to anyone who reads it. This gives a broader aspect for further research in David's Psalm if it is customisable to an individual or not though they have lyrical qualities. Making Psalm 23 a world-class is because of the one theme from the first halfline, "The LORD is my shepherd". The word shepherd encompasses all the expectations of a human: presence, provision, and protection. This Psalm is read in movies because of the profound themes and structural language. Indeed, it is one of the most influential Psalms with its simple, elegant and poised languages in English poetry that is relevant and related today.

\section{References}

1. Brewster S. Lyric (First Edition). Routledge. 2009.

2. Burton SH. The Criticism of Poetry. Longman. 1950.

3. Enright CDEDJ. English Critical Texts: 16th Century to 20th Century. OUP. 2009.

4. Futato MD, Jr., DHM. Interpreting the Psalms: An Exegetical Handbook (Handbooks for Old Testament Exegesis) (Illustrated ed.). Kregel Academic \& Professional. 2007.

5. GIWU. Psalm 23 - The Lord is My Shepherd (With words - KJV). 2017, September 29. [Video]. YouTube. https://www.youtube.com/watch?v=nGARAgxn4fw

6. Greene R. Lyric. In G. P. Norton (Ed.), The Cambridge History of Literary Criticism. Cambridge University Press. 1999;3:216-228.

7. Gregory Bateson Quotes. 2021. Brainy Quote. https://www.brainyquote.com/quotes/gregory_bateson_ 320288

8. King James Version (Cambridge Edition). 1611. King James. https://www.kingjamesbibleonline.org

9. Klien WL. Why We Punctuate; Or, Reason Vs. Rule in the Use of Marks. By a Journalist. The Lancelot. 1897.

10. McLane MN, Chandler J. Romantic metre and form. In The Cambridge Companion to British Romantic Poetry (Cambridge Companions to Literature) (1st ed., Cambridge University Press. 2008, 53-75.

11. Metaphor. In Stanford Encyclopedia of Poetry. 2016. https://plato.stanford.edu/entries/metaphor

12. Quackenbush KC, Quackenbush DA. Stylistics Analysis of Psalm of Life. International Journal of Scientific and Research Publications (IJSRP). 2019;9(3):129-135. https://doi.org/10.29322/ijsrp.9.03.2019.p8723

13. Quackenbush KC, Quackenbush DA, Epe PKC, Epe PITC. Stylistics Analysis of Sonnet 18 by William Shakespeare. International Journal of Applied Research, 2019;5(5):233-237.

https://www.allresearchjournal.com/archives/?year=201 9\&vol=5\&issue=5\&part=D\&Article Id=5857.

14. rhyme scheme | poetry. (2012, July 27). Encyclopedia Britannica. https:/www.britannica.com/art/rhymescheme

15. Short MH, Leech GN. Style and Choice. In Style in Fiction: A Linguistic Introduction to English Fictional Prose (English Language) (2nd ed.,). 2007, 9-31. Routledge.
16. The Economist. Out with the long. The Economist. 2008, August 14.

https:/www.economist.com/leaders/2004/10/07/outwith-the-long 